Article

\title{
Environmental Efficiency Evaluation in the Top Asian Economies: An Application of DEA
}

\author{
Chia-Nan Wang $1, * \mathbb{1}$, Hoang-Phu Nguyen $1,2, * \mathbb{C}$ and Cheng-Wen Chang $1, *$ \\ 1 Department of Industrial Engineering and Management, National Kaohsiung University of Science and \\ Technology, Kaohsiung 80778, Taiwan \\ 2 School of Business, Ho Chi Minh International University, Vietnam National University, \\ Ho Chi Minh City 70000, Vietnam \\ * Correspondence: cn.wang@nkust.edu.tw (C.-N.W.); nhphu@hcmiu.edu.vn (H.-P.N.); \\ maxchang@nkust.edu.tw (C.-W.C.)
}

check for updates

Citation: Wang, C.-N.; Nguyen, H.-P.; Chang, C.-W. Environmental Efficiency Evaluation in the Top Asian Economies: An Application of DEA. Mathematics 2021, 9, 889. https://doi.org/10.3390/math9080889

Academic Editors: David Barilla and Eleni Zafeiriou

Received: 25 February 2021

Accepted: 13 April 2021

Published: 16 April 2021

Publisher's Note: MDPI stays neutral with regard to jurisdictional claims in published maps and institutional affiliations.

Copyright: (C) 2021 by the authors. Licensee MDPI, Basel, Switzerland. This article is an open access article distributed under the terms and conditions of the Creative Commons Attribution (CC BY) license (https:/ / creativecommons.org/licenses/by/ $4.0 /)$.

\begin{abstract}
Sustainable development has become a global catchphrase in the recent development age This leads to the growth of various methodologies in evaluating environmental efficiency, such as the Data Envelopment Analysis (DEA) method. The purpose of this study is to propose an extended DEA model, i.e., the undesirable output model, in measuring the relative eco-efficiency scores across nations. The study collected the data of inputs, namely bad outputs and good outputs of the top 20 Asian economies in the period of 2005-2019, and then estimated the environmental efficiency of each country and classified them. The results have shown that there are four nations having higher average environmental efficiency than others. Japan is a good example of sustainable development that simultaneously balances economic development and environmental protection. The study has also discussed possible solutions for improvement to the group of nations with low environmental efficiency. Contributing to applying a novelty extended DEA model, this work recommends a more precise model, taking the weight of outputs into account for further studies.
\end{abstract}

Keywords: undesirable output model; DEA model; sustainable development; environmental efficiency; green growth; eco-efficiency

\section{Introduction}

In recent years, the concept of sustainable development has been attracting many concerns from different countries. Environmental efficiency has been gaining a lot of attention in regard to both the theoretical and practical meaning [1]. The long-term sustainable economic development is defined by achieving the most economic benefits while making the least damage to the environment [2]. The natural capital depletion, the generation of waste, and the growth of the population have many impacts on the natural environment, such as pollution, natural disasters, and the loss of biodiversity. The sea level is predicted to rise to $2 \mathrm{~m}$ in 80 years, due to global warming and climate change [3]. Conrad and Cassar (2014) [4] argued that the sustainable economic growth keeping a balance between pollution and economic development is a concern for both small and large countries.

\subsection{Why ASIA?}

The booming economy in the Asia region leads governments to consider social and environmental challenges because most of the current developing model in the region much depend on natural resources.

According to the projection report of the US Energy Information Administration (EIA), world energy consumption will increase by nearly 50\% in the next 30 years. The Organization for Economic Cooperation and Development (OECD) has reported that this growth comes mainly from the Asia region which economy is still a key driving demand [5]. 
In Asia nations, most cities and industrial zones have been already shaped and led to an increase in the levels of pollution as well as energy consumption.

In the European Union, the member countries have agreed to imply the "green growth" through developing policies related to a sustainable environmental framework [6]. Likewise, the Greenhouse Gas Emission Reduction from Industry in Asia (GERIAP) is a three-year project established to address climate change. Members of the project are supported to become more energy efficient by reducing greenhouse gas emissions and costs. For example, ASEAN countries have engaged the East Asia Climate Partnership (EACP) programmed in 2012, which is a two-year horizontal project by OECD to help promote green growth in line with the region's development objectives.

\section{2. "Green Growth" Measurements}

The United Nations Economic and Social Commission for Asia and Pacific (UNESCAP) has defined that one of the key changes in the way of producing and consuming resources is "Eco-efficiency", which is also used to measure green growth. Economic development is considered as a "green growth" if it has a high eco-efficiency. It means that the resources used in production are both efficient (i.e., minimizing the resource inputs) and productive (i.e., maximizing the added value of outputs). To measure green growth, the environmental efficiency indicators (EEIs) is designed to capture the ecological efficiency of growth The ultimate goal of the EEIs is to provide a practical tool for governments in making socioeconomic policies regarding environmental sustainability.

Many studies concentrate on eco-efficiency analysis that is not easy and reply on various factors. There are parametric and non-parametric methodologies in measuring energy efficiency. Parametric Stochastic Frontier Analysis (SFA) may have a multicollinearity problem due to the assumption of the production function, meanwhile, the Non-parametric Data Envelopment Analysis (DEA) method can deal with the complicated situation of multiple inputs-outputs. Zhu et al. (2019) [2] argued that an extended DEA that can accommodate undesirable outputs is a comprehensive eco-efficiency evaluation method. In which, there are all the identification problems of decision-making units (DMUs), possible slacks of variables, and the problems of an insufficient number of available DMUs and intertemporal comparability.

Seiford and Thrall (1990) [7] argued that one important benefit of DEA is that one does not need to make any assumptions regarding the relationship between inputs and outputs. We can use this model to measure the efficiency performances of comparable DMUs which have multiple inputs and likewise outputs. Even in conditions, we have fully accurate information on their values and no knowledge about the production or cost function [8].

The purpose of our study is to apply the novelty approach with DEA to evaluate the eco-efficiency of the top 20 economies of Asia, during the period 2005-2019, trying to classify them. The environment efficiency indicators for each country will be obtained from some input indicators and based on the desirable outputs (which are expected to be as high as possible) and undesirable outputs (which we want to reduce as much as possible). We present the results graphically to analyze and propose the final classification more objectively. Moreover, we will propose some solutions with alternative improving environmental efficiency with general character.

\section{Literature Review}

The development of any industry and economy always goes along with energy consumption as a driver. A global trend is the sustainable development that countries must consider a balance between economic growth and environmental efficiency. In fact, there is a closely relationship between energy consumption, gross domestic product (GDP), and $\mathrm{CO}_{2}$ emission [9]. In their study, Hermoso-Orzáez et al. (2020) [10] set the inputs including Energy consumption from fossil fuels (i.e., gas, oil, and nuclear energy) and outputs, including GDP and $\mathrm{CH}_{4}$ and $\mathrm{CO}_{2}$ emissions, to calculate the relative environmental efficiency (eco-efficiency) of the 28 member countries of the European Union (EU) 
through the DEA method. Their paper found that there are 14 of the 28 nations having a high relative environmental efficiency.

Energy is considered as one of the important inputs in production since most economic activities are highly related to fossil fuels. However, there are a few relevant academic studies that a foundation for political agendas on energy efficiency and carbon reduction. The relationship between energy consumption and GDP has attracted the attention of many scholars, especially in China. For example, Wang, Yu, and Zhang (2013) [11]; Li and Lin (2015) [12] evaluated the relationship between energy efficiency and economic growth of provinces and cities in China. They found that the worst energy efficiency and the highest energy efficiency are respectively in western and eastern China.

Moreover, many studies indicated a causal relationship between GDP and $\mathrm{CO}_{2}[7,8]$. The worsening global climate change renders the issues related to carbon emissions. There are many serious environmental impacts if a government implements policies shifting from an agriculture orientation to an industrial centric. It is necessary to control environmental pollution due to an indispensable tendency of sustainable development. The relationship between the GDP growth and greenhouse gases (i.e., including $\mathrm{CO}_{2}$ and $\mathrm{CH}_{4}$ ) reduction, hence, becomes a significant indicator to evaluate environmental efficiency [13].

Most works from the literature focus on energy efficiency and discuss on government's policies regarding carbon emissions, public expenditures, and economic growth. For example, in their study, Wen-Hsien et al. (2016) [9] included inputs (i.e., government expenditures, labor force, and energy consumption) and outputs (i.e., GDP and $\mathrm{CO}_{2}$ emissions) to analyze sustainability. Few studies concentrate on evaluating environmental efficiency. To have more precise insights of sustainable evaluation, the inputs and outputs selection must be paid much attention. In this study, the authors consider choosing inputs and outputs related to direct environmental impacts. In addition to energy consumption as an input, the number of vehicles using fossil fuels in each country is added as another input in Hermoso-Orzáez et al. (2020) [10]. Then, the author also set other greenhouse gases, which have a large incidence of climate change, particularly methane $\left(\mathrm{CH}_{4}\right)$ as an undesirable output. This paper, hence, proposes a research model that is expected to have good indicators in evaluating environmental efficiency among countries.

\subsection{Data Envelopment Analysis (DEA) Method}

Farrell (1957) [14] is a pioneer in studying the Data Envelopment Analysis (DEA) method. This is a "data oriented" approach converting multiple inputs into multiple outputs. Wang et al. (2016) [15] reported that various DEA models and DEA-based modeling approaches such as CCR (Charnes-Cooper-Rodes); Undesirable Outputs, Malmquist, and Window have been recently applied in both private and public sectors across countries. For example, the CCR-DEA is applied to study the cost-effectiveness of electricity distribution facilities in Brazil [16] or performance-efficiency among Vietnamese steel manufacturers [17]. The studies applied to measure sustainability in supply chains with DEA techniques are very remarkable [18]. It can also be used to calculate environmental efficiency $[19,20]$ (see more in Appendix A).

Charnes et al. (1978) proposed a method to calculate technical efficiency by solving a problem of nonlinear programming. Considering that we have $\mathrm{n}$ "decision-making unit" (DMUs) denoted as $j=(1,2, \ldots, \mathrm{n})$, and for each DMU, we have $m$ inputs $x_{i j}(i=1,2, \ldots$, $\mathrm{m})$ and outputs $y_{r j}(r=1,2, \ldots, \mathrm{s})$; this problem of linear programming can be expressed in the Equation (1) [21].

$$
\begin{gathered}
E_{0}=\operatorname{Max} \frac{\text { Outputs }}{\text { Inputs }}=\operatorname{Max} \frac{\sum_{r} u_{r} y_{r o}}{\sum_{i} v_{i} x_{i o}} \\
\text { s.t } \sum_{r} u_{r} y_{r j}-\sum_{i} v_{i} x_{i j} \leq 0 \\
u_{r}, v_{i} \geq \varepsilon
\end{gathered}
$$


where $x_{i o}$ are the inputs, $y_{r o}$ are the outputs, $j$ the set of decision making units (DMU), $r$ is the number of outputs, $i$ is the number of inputs, $u r$ and $v i$ are the weights assigned to the outputs and to the inputs, respectively, and $\varepsilon$ is a parameter to force the variables to be positive.

However, this problem of nonlinear programming can be translated into linear programming in the following way, Equation (2) [21]:

$$
\begin{gathered}
E_{0}=\operatorname{Max} \sum_{r} \mu_{r} y_{r o} \\
\text { s.t Sum of Inputs }=\sum_{i} v_{i} x_{i o}=1 \\
\sum_{r} \mu_{r} y_{r j}-\sum_{i} v_{i} x_{i j} \leq 0 \\
u_{r}, v_{i} \geq \varepsilon
\end{gathered}
$$

where $\mu_{r}=t u_{r}$ and $v_{i}=t v_{i}$, being $t=\left(\sum_{i} v_{i} x_{i o}\right)^{-1}$.

Policymakers are always concerned with sustainable development, which attains a balance between environmental issues and economic growth. The novelty of the proposed approach in this study was not only to discuss the problem from economical aspects by using DEA as a unified assessment, but also to separate outputs into desirable and undesirable types. Goto et al. (2014) [22] argue that such a split is crucial since energy industries usually produce both bad and good outputs.

\subsection{The Environmental Efficiency Index (EEI)}

We assume that there are 20 DMUs that correspond to the 20 top Asia economies, i.e., the value of $k$ ranges from 1 to 20. For each of the $\mathrm{DMU}_{\mathrm{k}}$, we have $\mathrm{N}$ inputs $x_{k}=\left(x_{1 k}, x_{2 k}, x_{3 k}, \ldots x_{n k}\right), \mathrm{M}$ desirable outputs $y_{k}=\left(y_{1 k}, y_{2 k}, y_{3 k}, \ldots y_{m k}\right)$, and J undesirable outputs $u_{k}=\left(u_{1 k}, u_{2 k}, u_{3 k}, \ldots u_{j k}\right)$. With all of these data, we proceed to operate by Tyteca's process (1997) [21]:

$$
\begin{gathered}
E E I=\operatorname{Min} \lambda \\
\text { s.t. } \sum_{1}^{k} z_{k} x_{n k} \leq x_{n}, n=1,2, \ldots N \\
\sum_{1}^{k} z_{k} y_{m k} \geq y_{m}, m=1,2, \ldots M \\
\sum_{1}^{k} z_{k} u_{j k}=\lambda u_{j}, j=1,2, \ldots \\
z_{k} \geq 0, k=1,2, \ldots, K
\end{gathered}
$$

where $k=$ number of DMUs, $n=$ number of inputs, $x=$ inputs, $y=$ desirable outputs, $M=$ number of desirable outputs, $z=$ undesirable outputs, and $j=$ number outputs.

In this way, DMUs that have higher EEIs from Equation (3) will have greater environmental efficiency.

\section{Materials and Methods}

\subsection{Research Process}

To reach our objectives, the study was divided into four parts, as illustrated in Figure 1 below. 


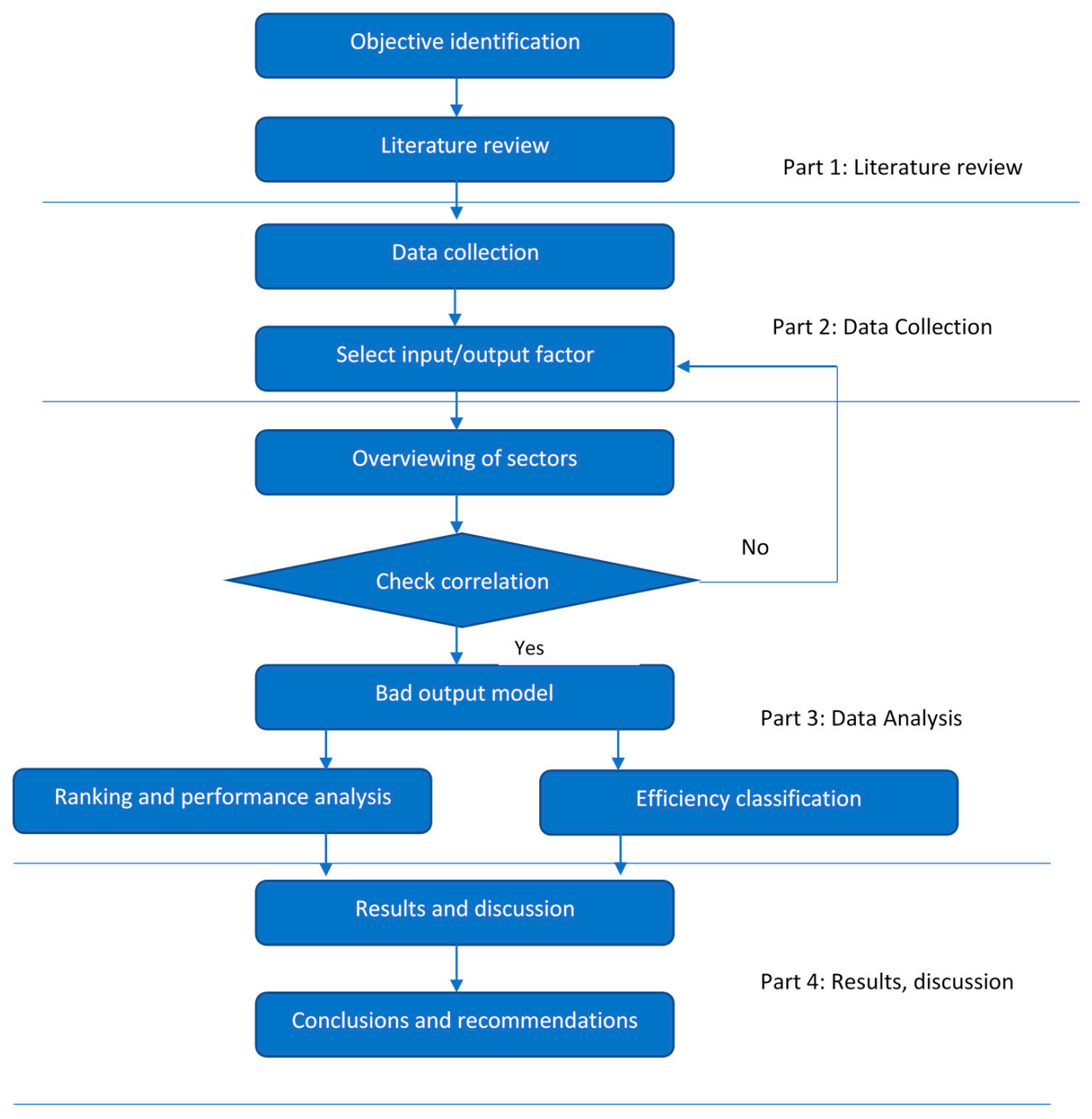

Figure 1. Research process.

\subsubsection{Part 1: Literature Review}

Problem identification is implemented in this part, and then the key works in the literature related to the research topic are reviewed and investigated in Section 2.

\subsubsection{Part 2: Data Collection}

This is a crucial part of the study. We follow the rule of [23] that the DEA requires the number of DMUs to be at least twice as greater as the total number of input and output variables. In the study, the authors intended to analyze the environmental efficiency of the top 20 Asian economies based on five indicates of inputs/outputs.

\subsubsection{Part 3: Data Analysis Is Divided into Three Basic Steps}

- Step 1: Reviewing DEA models to choose the Undesirable outputs model and DEASolver software in dealing with the problem of bad outputs and measuring the efficiency of DMUs (Appendix A).

- $\quad$ Step 2: The Pearson coefficient is implemented to the isotonic data. This step needs to be re-performed until the correlation closing to +1 ; it means that the input and output variables have a positive relationship. 
- Step 3: Data of 20 DMUs are estimated by DEA, and the results are analyzed in two directions: efficiency classification and overall rating. The authors will estimate the average value of environmental efficiency indicator (EEI) and classified into four groups, namely "Excellent" with $0.99<\mathrm{EEI}<1$, "Good" with $0.8<\mathrm{EEI}<0.9$, "Average" with $0.5<\mathrm{EEI}<0.79$, and "Improvable" with $0<\mathrm{EEI}<0.49$.

\subsubsection{Part 4: Analysis and Discussion}

The results of this analysis are then reviewed and summarized in a manner directly related to the research problem. Based on the results, the authors give some valuable information and recommendations for decision-makers.

\subsection{Reliable Data Sources}

These data in Table 1 are extracted from reliable resources namely the World Bank's online database (World Bank, 2020) and "Our World In Data", which is a project of the Global Change Data Lab, a registered charity in England and Wales; National Statistics Republic of China (Taiwan); the Global Carbon Project: Global Carbon Project. (2020), International Organization of Motor Vehicle Manufacturers.

Table 1. Names of countries and decision-making units (DMUs) in respective (gross domestic product (GDP) in billion US dollars). Source: World Bank.

\begin{tabular}{cccccccc}
\hline No. & DMUs & Countries/Regions & $\begin{array}{c}\text { GDP } \\
\text { (in 2019) }\end{array}$ & No. & DMUs & Countries/Regions & $\begin{array}{c}\text { GDP } \\
\text { (in 2019) }\end{array}$ \\
\hline 1 & DMU1 & China & 14343 & 11 & DMU11 & Israel & 395 \\
2 & DMU2 & Japan & 5082 & 12 & DMU12 & Philippines \\
3 & DMU3 & India & 2875 & 13 & DMU13 & Singapore & 377 \\
4 & DMU4 & South Korea & 1642 & 14 & DMU14 & Hong Kong & 366 \\
5 & DMU5 & Indonesia & 1119 & 15 & DMU15 & Malaysia & 365 \\
6 & DMU6 & Saudi Arabia & 793 & 16 & DMU16 & Bangladesh & 303 \\
7 & DMU7 & Taiwan & 605 & 17 & DMU17 & Pakistan & 278 \\
8 & DMU8 & Thailand & 544 & 18 & DMU18 & Vietnam & Iraq \\
9 & DMU9 & Iran & 445 & 19 & DMU19 & Qatar \\
10 & DMU10 & United Arab Emirates & 421 & 20 & DMU20 & & 234 \\
\hline
\end{tabular}

\subsection{Data Collection}

In Part 2 of our study, we set 20 countries of the Asia region as decision-making units. The data of the inputs and outputs to estimate environmental efficiency are collected in the period of 2005-2019, since there are no available published data more recent from some of the nations. Moreover, we did not consider the data of 2020, due to the covid-19 pandemic that may lead to inaccurate measurements.

In the evaluation of environmental efficiency by using DEA, inputs/outputs selection is a crucial stage [24-26]. There are a lot of different studies on efficiency analysis, but there is no standard for selecting variables appropriately. In conventional energy efficiency measures, energy is used as a single input to generate GDP. Hu and Wang (2006) [27] believe that a single energy input cannot produce any output; it means that energy must be combined with other factors (such as labor and capital).

\subsubsection{Inputs Selection}

The objective of the study relates to sustainable development that balances between environmental efficiency and economic efficiency, so we must consider the inputs that can lead to both positive and negative outputs. In any country, the economic growth is associated with the transportation development and energy consumption. These are also two main sources of greenhouse gases (such as $\mathrm{CO}_{2}$ and $\mathrm{CH}_{4}$ ) that lead to air pollutants and climate change. 
Most countries generated energy from coal, oil, and nuclear origin sources to develop the economics. Taking the studies of References $[10,24,28]$ as foundations, the authors have selected the first input that is the primary energy consumption measured in terawatthours (TWh).

In addition, the transportation growth has led to a corresponding increase in the number of vehicles consuming fuel, which, in turn, has led to an increase in greenhouse gas emissions $[10,29]$. Hence, the authors have selected the number of vehicles as the second input.

\subsubsection{Outputs Selection}

The energy-consumption structure is still dominated by fossil energy; many carbon emissions, wastewater, and waste gas that have a serious impact on the environment are generated. In their studies, Feng et al. (2017) [30], Wang et al. (2019) [31], and HermosoOrzáez et al. (2020) [10] included these factors as undesirable outputs when evaluating environmental efficiency, and GDP is generally considered as the expected desirable output. The variables will also vary depending on the different subjects.

There are studies that apply DEA methodology with undesirable outputs, such as $\mathrm{SO}_{\mathrm{x}}$ and $\mathrm{NO}_{x}$ [32]; $\mathrm{CO}_{2}$ [10,33]; and $\mathrm{CH}_{4}$ emissions [34]. However, many previous studies have used $\mathrm{CO}_{2}$ and $\mathrm{CH}_{4}$ emissions as the undesirable outputs that detract from eco-efficiency in the country because these two greenhouse gases that have a large incidence on climate change and reducing environmental efficiency.

On the other hand, the higher desirable outputs contribute to have greater ecoefficiency. Energy consumption has been a major in continuous consumption of goods from energy-demanding sectors, such as production and manufacturing. Such an input, hence, has an essential effect on the country's gross domestic product (GDP) that accounts for the economic situation of a country, since the ratio between the two factors affects the economic output of several countries [9,35]. The GDP, therefore, is selected as a desirable output.

With the reasons above, and taking previous studies as examples, we considered all the inputs/outputs in our study, as shown in Table 2 below.

Table 2. List of inputs, desirable outputs, and undesirable outputs selected.

\begin{tabular}{ccc}
\hline Inputs & Desirable Outputs & Undesirable Outputs \\
\hline $\begin{array}{c}\text { Energy consumption from } \\
\text { coal, oil, gas sources } \\
\text { Volume of vehicles }\end{array}$ & GDP & $\mathrm{CO}_{2}$ emission \\
$\mathrm{CH}_{4}$ emission \\
\hline
\end{tabular}

\subsection{Undesirable Outputs Model}

Tone (2001) [23] applied a slack-based measure of efficiency (SBM) that is non-radial and non-oriented model, and utilizes input and output slacks directly in producing an efficiency measure. Cooper et al. (2006) [25] proposed an undesirable output model that modified SBM to account for "Bad" outputs. This study uses BadOutput model (BadOutput-C) as follows:

Let $Y^{g}$ be good matrices as desirable output and $Y^{b}$ be bad matrices as undesirable output. For each country, it is as $\operatorname{DMU}\left(x_{0}, y_{0}{ }^{g}\right.$, and $\left.y_{0}{ }^{b}\right)$.

The production possibility set was defined by Equation (4):

$$
P=\left\{\left(x, y^{g}, y^{b}\right) \mid x \geq X \lambda, y^{g} \leq Y^{g} \lambda, y^{b} \geq Y^{b} \lambda, L \leq e \lambda \leq U, \lambda \geq 0\right\}
$$

where $\lambda$ is the intensity vector, $L$ is the lower bounds of $\lambda$, and $U$ is the upper bounds of $\lambda$.

The efficiency DMU in this frame was defined as follows.

An efficiency DMU $\left(x_{0}, y_{0}^{g}\right.$, and $\left.y_{0}^{b}\right)$ in the bad outputs, if there was no vector $\left(x, y^{g}, y^{b}\right) \in P$ such that $x_{0}>x, y_{0}^{g}<y^{g}, y_{0}^{b}>y^{b}$ with at least one strict inequality. 
The modified SBM for the undesirable model is as Equation (5) follows:

$$
\rho^{*}=\min \frac{1-\frac{1}{m} \sum_{i=1}^{m} \frac{s_{i 0}^{-}}{x_{i o}}}{1+\frac{1}{s}\left(\sum_{r=1}^{s_{1}} \frac{s_{r}^{g}}{y_{r 0}^{g}}+\sum_{r=1}^{s_{2}} \frac{s_{r}^{b}}{y_{r 0}^{b}}\right)}
$$

This is subject to the following:

$$
x_{0}=X \lambda+s^{-} ; y_{0}^{g}=Y \lambda-s^{g} ; y_{0}^{b}=Y \lambda+s^{b} ; L \leq e \lambda \leq U ; s^{-} ; s^{g}, s^{b} ; \lambda \geq 0
$$

The vectors $s^{-}, s^{b}$, and $s^{g}$ respectively represent to excesses in inputs; bad outputs and shortages in good outputs. $S_{1}$ and $S_{2}$ denote the number of elements in $s^{b}, s^{g}$, and $s=S_{1}+S_{2}$.

$\operatorname{A~DMU~}\left(x_{0}, y_{0} \mathrm{~g}\right.$, and $\left.y_{0} \mathrm{~b}\right)$ was efficient if and only if $\rho^{*}=1$, i.e., $s^{-*}=s^{b *}=s^{g *}=0$.

$\operatorname{ADMU}\left(x_{0}, y_{0}{ }^{\mathrm{g}}\right.$, and $\left.y_{0}{ }^{\mathrm{b}}\right)$ was inefficient if $\rho^{*}<1$.

Based on the above fractional program, we use Charnes-Cooper transformation and consider the dual side of the linear program in the variables $v, u^{g}$, and $u^{b}$ for constant returns to scale case, i.e., $\mathrm{L}=0$ and $\mathrm{U}=\infty$. As Equation (6)

$$
\max u^{g} y_{0}^{g}-v x_{0}-u^{b} y_{0}^{b}
$$

Subject to $u^{g} Y^{g}-v X-u^{b} Y^{b} a \leq 0$

$$
\begin{gathered}
v a \geq \frac{1}{m}\left[1 / x_{0}\right] \\
u^{g} \geq \frac{1+u^{g} y_{0}^{g}-v x_{0}-u^{b} y_{0}^{b}}{s}\left[1 / y_{0}^{g}\right] \\
u^{b} \geq \frac{1+u^{g} y_{0}^{g}-v x_{0}-u^{b} y_{0}^{b}}{s}\left[1 / y_{0}^{b}\right]
\end{gathered}
$$

where $v, u^{b}$, and $u^{g}$ are interpreted as the virtual prices (costs) of inputs, bad outputs, and good outputs, respectively. In the case, the optimal profit $u^{g} y^{g}{ }_{0}-v x_{0}-u^{b} y^{b}$ is at best zero, i.e., the concerned DMU is efficient.

In addition, it is necessary to set weights to good and bad outputs with $w_{1}$ and $w_{2}$ respectively. Then, the model calculated the relative weights as $W_{1}=s w_{1} /\left(w_{1}+w_{2}\right)$ and $W_{1}=s w_{2} /\left(w_{1}+w_{2}\right)$ and the objective function was modified to the Equation (7) following:

$$
\rho^{*}=\min \frac{1-\frac{1}{m} \sum_{i=1}^{m} \frac{s_{i 0}^{-}}{x_{i 0}}}{1+\frac{1}{s}\left(W_{1} \sum_{r=1}^{s_{1}} \frac{s_{r}^{g}}{y_{r 0}^{g}}+W_{2} \sum_{r=1}^{s_{2}} \frac{s_{r}^{b}}{y_{r 0}^{b}}\right)}
$$

In this study, we used the defaults of Cooper et al. with $W_{1}=W_{2}=1$.

\section{Results}

\subsection{Statistical Description}

To have greater precision in the final evaluation process, a statistical description was implemented as a whole and is shown in Table 3. Meanwhile, the environmental efficiency is estimated for each nation in the years. 
Table 3. Statistical study of inputs and outputs for the 20 top Asian economies in 2005-2019.

\begin{tabular}{cccccc}
\hline & Indicator & Unity & Max & Min & Average \\
\hline \multirow{2}{*}{ Inputs } & $\begin{array}{c}\text { Energy consumption from } \\
\text { coal, oil, gas source } \\
\text { Volume of Vehicles }\end{array}$ & $\begin{array}{c}\text { Terawatt-hours (TWh) } \\
\text { Thousands of vehicles }\end{array}$ & $39,360.93$ & 189.63 & 3153.05 \\
& GDP & Billions of Dollars (Bil.\$) & $14,342.90$ & 44.53 & $17,764.63$ \\
\hline Desirable Outputs & $\mathrm{CO}_{2}$ Emissions & Kilotons (Kts) & 10,175 & 30.27 & 7103.84 \\
\hline Undesirable & $\mathrm{CH}_{4}$ Emissions & $\begin{array}{c}\text { Kilotons carbon dioxide } \\
\text { equivalents (Kts CO } 2 \mathrm{e})\end{array}$ & 1328.50 & 2.26 & 789.85 \\
& & & & 145.90 \\
\hline
\end{tabular}

As for the consumption of energy from coal, oil, and gas sources during the period 2005-2019, the maximum value of average (31,103 TWh) is recorded in China, while the lowest values are recorded in countries such as Israel, Bangladesh, and Hong Kong, with 279,302 , and 320 (TWh) on average, respectively.

Regarding the volume of vehicles, the maximum value is reached in China in the year 2019 with 253,872 thousand of registered vehicles (CEIC, 2020) and the minimum volume is found in Bangladesh in 2005.

In terms of GDP, China has the highest GDP with 14,342 billions of dollars (Bil.\$) in 2019, while the lowest GDP is recorded in Qatar, in 2019, with 175 Bil.\$ and 44 Bil.\$ in 2005.

In carbon dioxide emission, there are three countries with the top $\mathrm{CO}_{2}$ emission, namely China, India, and Japan; meanwhile, Hong Kong, Singapore, and Bangladesh are nations that have the lowest records in $\mathrm{CO}_{2}$ emission

For the methane emission during the 2005-2019 period, the highest values are recorded in China, India, and Indonesia, with more than $500 \mathrm{Kts} \mathrm{CO}_{2} \mathrm{e}$ on average. However, Singapore and Hong Kong are two countries with the lowest value of $\mathrm{CH}_{4}$ emissions, around $3 \mathrm{Kts} \mathrm{CO}_{2} \mathrm{e}$ on average.

\subsection{Pearson Correlations}

In part 3, this study implements a simple Pearson correlation test to evaluate the association between input and output. The value of coefficient ranges from -1 (perfect negative) to 1 (perfect positive). A crucial requirement of applying DEA analysis is a positive correlation. The data of 2017-2019 are used to estimate correlations and an example in Table 4.

Table 4. Correlation coefficients of inputs and outputs in 2017. Source: Authors' estimation.

\begin{tabular}{cccccc}
\hline Variable & Energy Consumption & Volume of Vehicles & GDP & CO $_{2}$ Emissions & CH $_{4}$ Emissions \\
\hline Energy Consumption & 1 & $0.967^{* *}$ & $0.964^{* *}$ & $0.999^{* *}$ & $0.933^{* *}$ \\
Volume of Vehicles & $0.967^{* *}$ & 1 & $0.985^{* *}$ & $0.966^{* *}$ & $0.906^{* *}$ \\
GDP & $0.964^{* *}$ & $0.985^{* *}$ & 1 & $0.959^{* *}$ & $0.856^{* *}$ \\
$\mathrm{CO}_{2}$ Emissions & $0.999^{* *}$ & $0.966^{* *}$ & $0.959^{* *}$ & 1 & $0.944^{* *}$ \\
$\mathrm{CH}_{4}$ Emissions & $0.933^{* *}$ & $0.906^{* *}$ & $0.856^{* *}$ & $0.944^{* *}$ & 1 \\
\hline
\end{tabular}

** Correlation is significant at the 0.01 level (2-tailed).

These positive correlations prove that the selection of input and output variables is consistent.

\subsection{Performance Ranking-Undesirable Outputs Model}

\subsubsection{Undesirable Output Model Analysis}

In step 3 of part 3, the undesirable outputs (BadOutput-C) model is implemented by DEA Solver software to evaluate the relative environmental efficiency for the top 20 Asian economies from 2005 to 2019. 
The obtained results are relative, which does not mean that a country with a $100 \%$ efficiency score has perfect environmental efficiency; instead, this means that it is the most efficient among the countries we are studying [36].

The relative scores of each year of the countries are presented in Table 5. Then, we calculate the average environmental efficiency data in the period 2005-2019, as shown in Table 6.

Table 5. Environmental efficiency data for the 20 top GDPs in Asia during the 2005-2019 period. Source: Authors' estimation.

\begin{tabular}{|c|c|c|c|c|c|c|c|c|c|c|c|c|c|c|c|c|}
\hline & DMU & 2005 & 2006 & 2007 & 2008 & 2009 & 2010 & 2011 & 2012 & 2013 & 2014 & 2015 & 2016 & 2017 & 2018 & 2019 \\
\hline China & DMU1 & 0.123 & 0.127 & 0.138 & 0.155 & 0.165 & 0.170 & 0.181 & 0.175 & 0.179 & 0.172 & 0.169 & 0.164 & 0.169 & 0.172 & 0.162 \\
\hline Japan & DMU2 & 1 & 1 & 1 & 1 & 1 & 1 & 1 & 1 & 1 & 1 & 0.647 & 1 & 1 & 1 & 1 \\
\hline India & DMU3 & 0.123 & 0.130 & 0.149 & 0.127 & 0.144 & 0.167 & 0.162 & 0.140 & 0.133 & 0.127 & 0.121 & 0.125 & 0.138 & 0.126 & 0.123 \\
\hline South Korea & DMU4 & 0.281 & 0.307 & 0.321 & 0.251 & 0.243 & 0.273 & 0.275 & 0.254 & 0.267 & 0.268 & 0.246 & 0.245 & 0.260 & 0.259 & 0.236 \\
\hline Indonesia & DMU5 & 0.132 & 0.159 & 0.167 & 0.180 & 0.202 & 0.257 & 0.265 & 0.237 & 0.222 & 0.209 & 0.190 & 0.198 & 0.208 & 0.187 & 0.178 \\
\hline Saudi Arabia & DMU6 & 0.184 & 0.198 & 0.199 & 0.220 & 0.182 & 0.203 & 0.239 & 0.230 & 0.223 & 0.199 & 0.157 & 0.151 & 0.154 & 0.165 & 0.157 \\
\hline Taiwan & DMU7 & 0.487 & 0.625 & 0.737 & 0.775 & 0.834 & 1 & 1 & 1 & 1 & 1 & 1 & 1 & 1 & 1 & 1 \\
\hline Thailand & DMU8 & 0.114 & 0.132 & 0.145 & 0.145 & 0.149 & 0.166 & 0.165 & 0.151 & 0.151 & 0.132 & 0.121 & 0.122 & 0.132 & 0.135 & 0.138 \\
\hline Iran & DMU9 & 0.087 & 0.093 & 0.111 & 0.118 & 0.125 & 0.141 & 0.151 & 0.139 & 0.097 & 0.081 & 0.069 & 0.070 & 0.070 & 0.064 & 0.056 \\
\hline $\begin{array}{c}\text { United Arab } \\
\text { Emirates }\end{array}$ & DMU10 & 0.345 & 0.402 & 0.377 & 0.359 & 0.302 & 0.333 & 0.366 & 0.342 & 0.324 & 0.305 & 0.235 & 0.228 & 0.236 & 0.240 & 0.228 \\
\hline Israel & DMU11 & 0.403 & 0.421 & 0.454 & 0.662 & 0.683 & 0.741 & 0.751 & 0.558 & 1 & 1 & 1 & 1 & 1 & 1 & 1 \\
\hline Philippines & DMU12 & 0.218 & 0.266 & 0.283 & 0.316 & 0.334 & 0.374 & 0.394 & 0.393 & 0.391 & 0.371 & 0.326 & 0.313 & 0.292 & 0.284 & 0.284 \\
\hline Singapore & DMU13 & 0.428 & 0.440 & 0.482 & 0.453 & 0.436 & 0.599 & 1 & 1 & 0.645 & 0.603 & 0.524 & 1 & 1 & 1 & 1 \\
\hline Hong Kong & DMU14 & 1 & 1 & 1 & 1 & 1 & 1 & 1 & 1 & 1 & 1 & 1 & 1 & 1 & 1 & 1 \\
\hline Malaysia & DMU15 & 0.110 & 0.118 & 0.128 & 0.134 & 0.131 & 0.157 & 0.168 & 0.152 & 0.146 & 0.139 & 0.117 & 0.111 & 0.115 & 0.124 & 0.118 \\
\hline Bangladesh & DMU16 & 1 & 1 & 1 & 1 & 1 & 1 & 1 & 1 & 1 & 1 & 1 & 1 & 1 & 1 & 1 \\
\hline Pakistan & DMU17 & 0.161 & 0.172 & 0.151 & 0.154 & 0.162 & 0.164 & 0.186 & 0.185 & 0.164 & 0.164 & 0.166 & 0.157 & 0.162 & 0.154 & 0.128 \\
\hline Vietnam & DMU18 & 0.167 & 0.195 & 0.176 & 0.162 & 0.181 & 0.173 & 0.173 & 0.175 & 0.176 & 0.167 & 0.153 & 0.154 & 0.155 & 0.151 & 0.142 \\
\hline Iraq & DMU19 & 0.106 & 0.134 & 0.172 & 0.227 & 0.190 & 0.211 & 0.254 & 0.260 & 0.256 & 0.243 & 0.174 & 0.152 & 0.171 & 0.180 & 0.166 \\
\hline Qatar & DMU20 & 0.197 & 0.252 & 0.280 & 0.353 & 0.306 & 0.348 & 0.413 & 0.385 & 0.379 & 0.340 & 0.226 & 0.197 & 0.197 & 0.207 & 0.189 \\
\hline
\end{tabular}

Table 6. Classification into categories based on average environmental efficiency for the top 20 GDP Asian economies in the period 2005-2019. Source: Authors' estimation.

\begin{tabular}{ccc}
\hline Hong Kong & DMU14 & 1 \\
Bangladesh & DMU16 & 1 \\
Japan & DMU2 & 0.97646 \\
Taiwan & DMU7 & 0.89709 \\
Israel & DMU11 & 0.77821 \\
Singapore & DMU13 & 0.70733 \\
Philippines & DMU12 & 0.32261 \\
United Arab Emirates & DMU10 & 0.30803 \\
Qatar & DMU20 & 0.28455 \\
South Korea & DMU4 & 0.26572 \\
Indonesia & DMU5 & 0.19943 \\
Iraq & DMU19 & 0.19291 \\
Saudi Arabia & DMU6 & 0.19082 \\
Vietnam & DMU18 & 0.16659 \\
Pakistan & DMU17 & 0.16197 \\
China & DMU1 & 0.16142 \\
Thailand & DMU8 & 0.13976 \\
India & DMU3 & 0.13565 \\
Malaysia & DMU15 & 0.13101 \\
Iran & DMU9 & 0.09813 \\
\hline
\end{tabular}

\subsubsection{Classification of Efficiency}

Based on the classifying method in the Hermoso-Orzáez et al. (2020), the values of average environmental efficiency for DMUs (i.e., countries) are divided into four categories as below: 
- "Excellent environmental efficiency" includes the countries with an average efficiency between 0.99 and 1.00 .

- "Good environmental efficiency" includes the countries with an average efficiency between 0.80 and 0.98 .

- "Average environmental efficiency" includes the countries with an average efficiency between 0.50 and 0.79 .

- "Improvable environmental efficiency" includes the countries with an average efficiency between 0.00 and 0.49 .

In this way, according to the relative average scores, the 20 Asia countries are classified into the different categories in Table 6:

- Two countries are in the category of "Excellent environmental efficiency", namely Hong Kong and Bangladesh, that is represented by the green color in Table 6 .

- Two countries are in the category of "Good environmental efficiency", namely Japan and Taiwan, that is represented by the yellow color in Table 6 .

- Two countries are in the category of "Average environmental efficiency", namely Israel and Singapore, that is represented by the orange color in Table 6 .

- Fourteen countries are in the category of "Improvable environmental efficiency", namely Philippines, United Arab Emirates, Qatar, South Korea, Indonesia, Iraq, Saudi Arabia, Vietnam, Pakistan, China, Thailand, India, Malaysia, and Iran, and they are represented by the red color in Table 6 .

\section{Discussion}

Over the period of 2005-2019, Figure 2 has shown that there are only six countries, namely Singapore, Israel, Taiwan, Bangladesh, Japan, and Hong Kong, which have an increasing trend in the value of environmental efficiency scores. Meanwhile, other countries have an unchanged or even a decrease tendency in the value over the period, for example, Qatar and Iran.

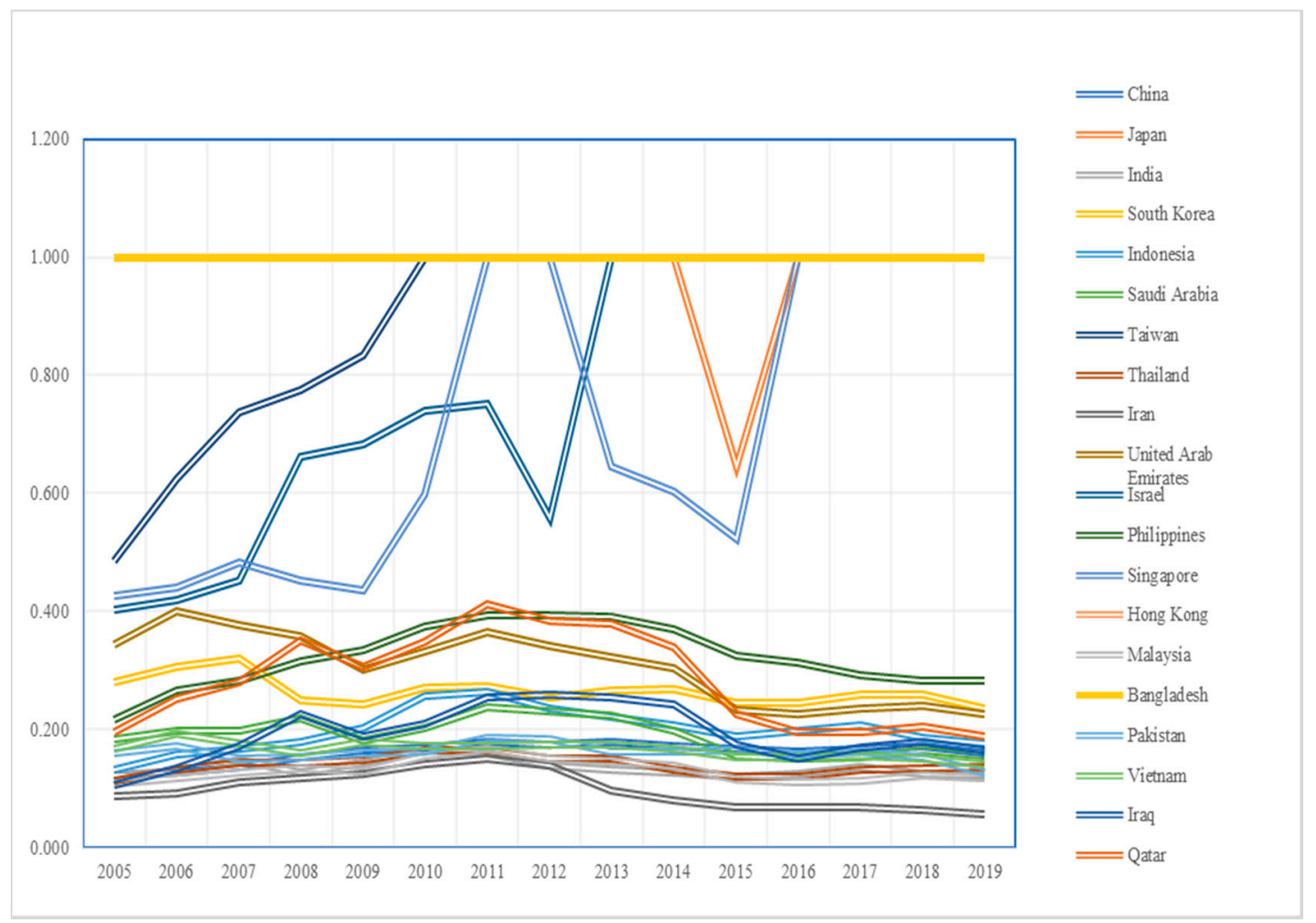

Figure 2. Changes in environmental efficiency score among countries in 2005-2019. Source: authors' estimation. 
From the finding, the authors realize that there are two different groups in taking the environmental efficiency into account. One group included nations that their governments have paid effort in improving the environment or at least having harm reduction by bad outputs, besides economic growth. Meanwhile, the other group still concentrates on developing its economy without having much attention to its environmental issues. This means that sustainable development is a tendency, but it has just happened in some Asian countries.

\subsection{Comparison between the Average EEI and the Inputs}

Figure 3 showed a comparison between the average environmental efficiency obtained with average energy consumption. We can see that most countries consumed a large amount of energy from coal, oil, and gas sources, which are recorded with a small value of the average environmental efficiency, for example, China, India, Iran, Saudi Arabia. On the other hand, Japan and Taiwan are two countries that accounted for the high value of average EEI despite their consumption of a large amount of energy.

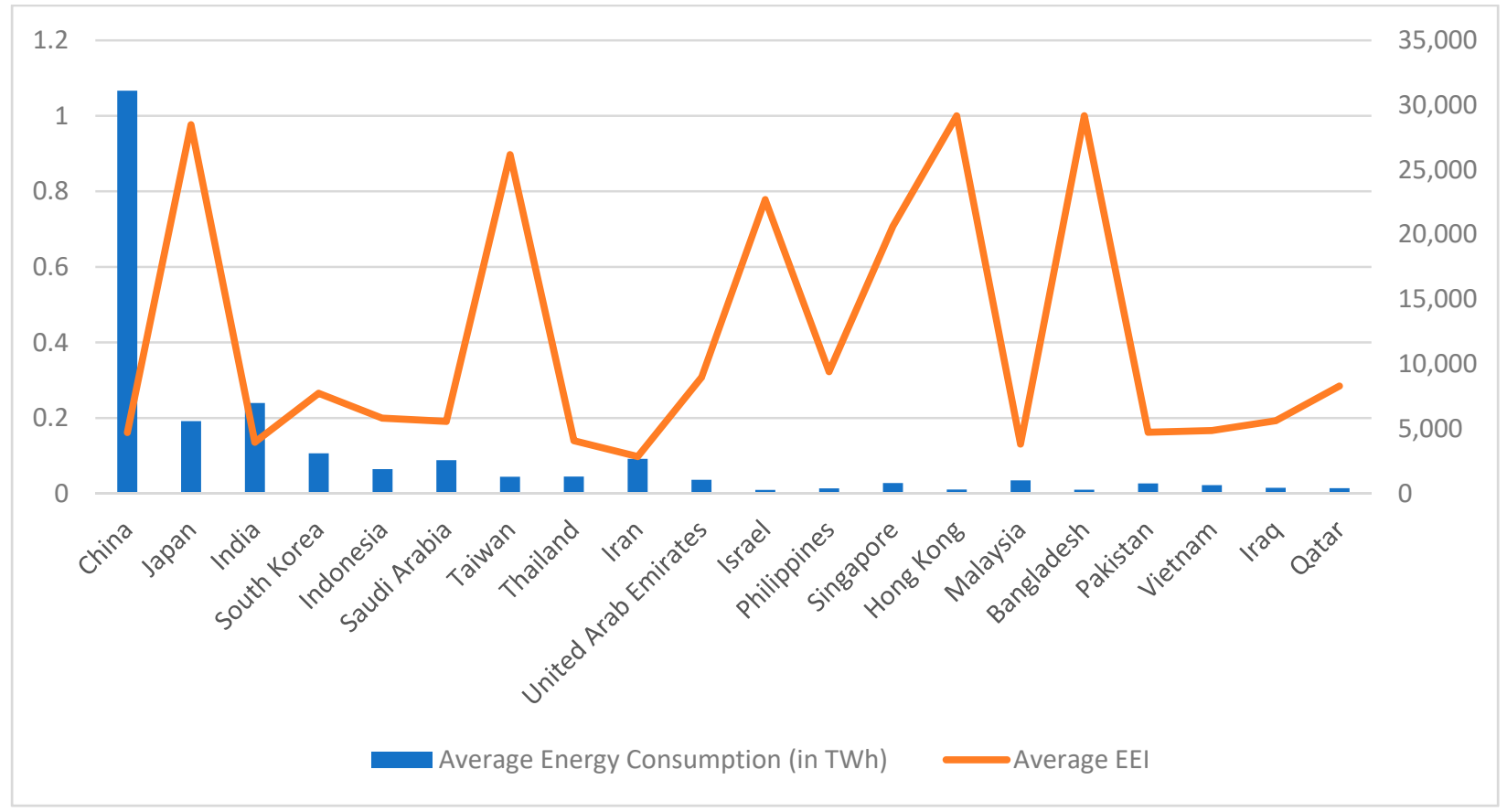

Figure 3. Comparison between the average environmental efficiency indicator (EEI) and the average energy consumption. Source: authors' estimation.

The authors found a similarity in the relation between the volume of registered vehicles and the EEI, as shown in Figure 4.

The comparison above has proved that our estimation of the environmental efficiency scores is relatively accurate. Despite having large numbers of vehicles, as well as high energy consumption, the countries, including Japan and Taiwan, keep a high environmental efficiency indicator. 


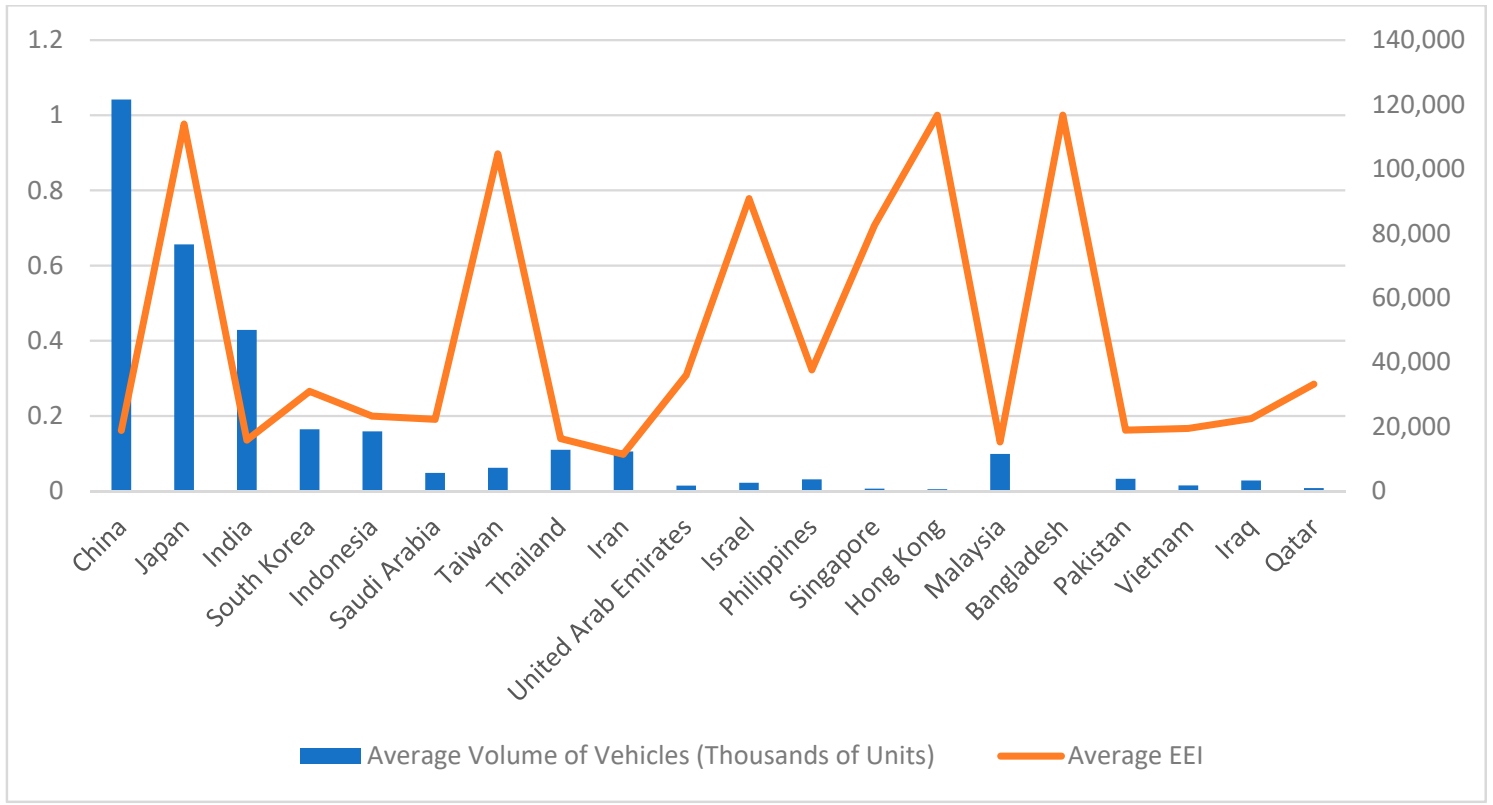

Figure 4. Comparison between the average EEI and the average Volume of Vehicles. Source: authors' estimation.

\subsection{Comparison between the Average EEI and the Outputs}

In terms of GDP, the relationship between the average environmental efficiency score and GDP is not clear in Figure 5. However, Figures 6 and 7 shows a negative association between the average EEI and bad outputs (i.e., $\mathrm{CO}_{2}$ and $\mathrm{CH}_{4}$ emission). There is no country with a high environmental efficiency score that accounted for the high value in undesirable outputs, for example, Japan, Taiwan, Singapore, Hong Kong, Israel, and Bangladesh. This point proves that one of the ways to improve environmental efficiency is controlling and reducing their $\mathrm{CO}_{2}$ and $\mathrm{CH}_{4}$ emissions.

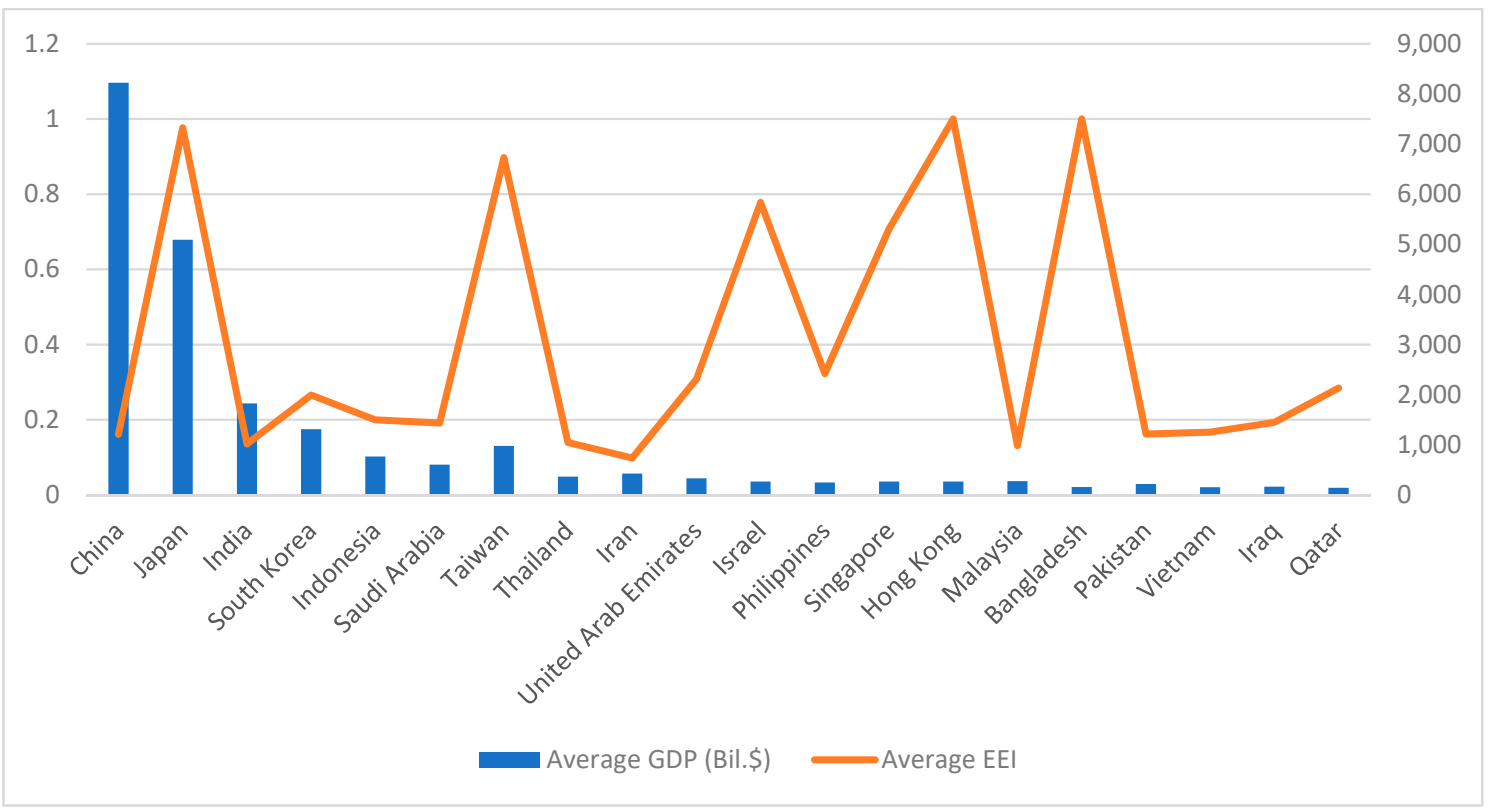

Figure 5. Comparison between the average EEI and the Average GDP. Source: authors' estimation. 


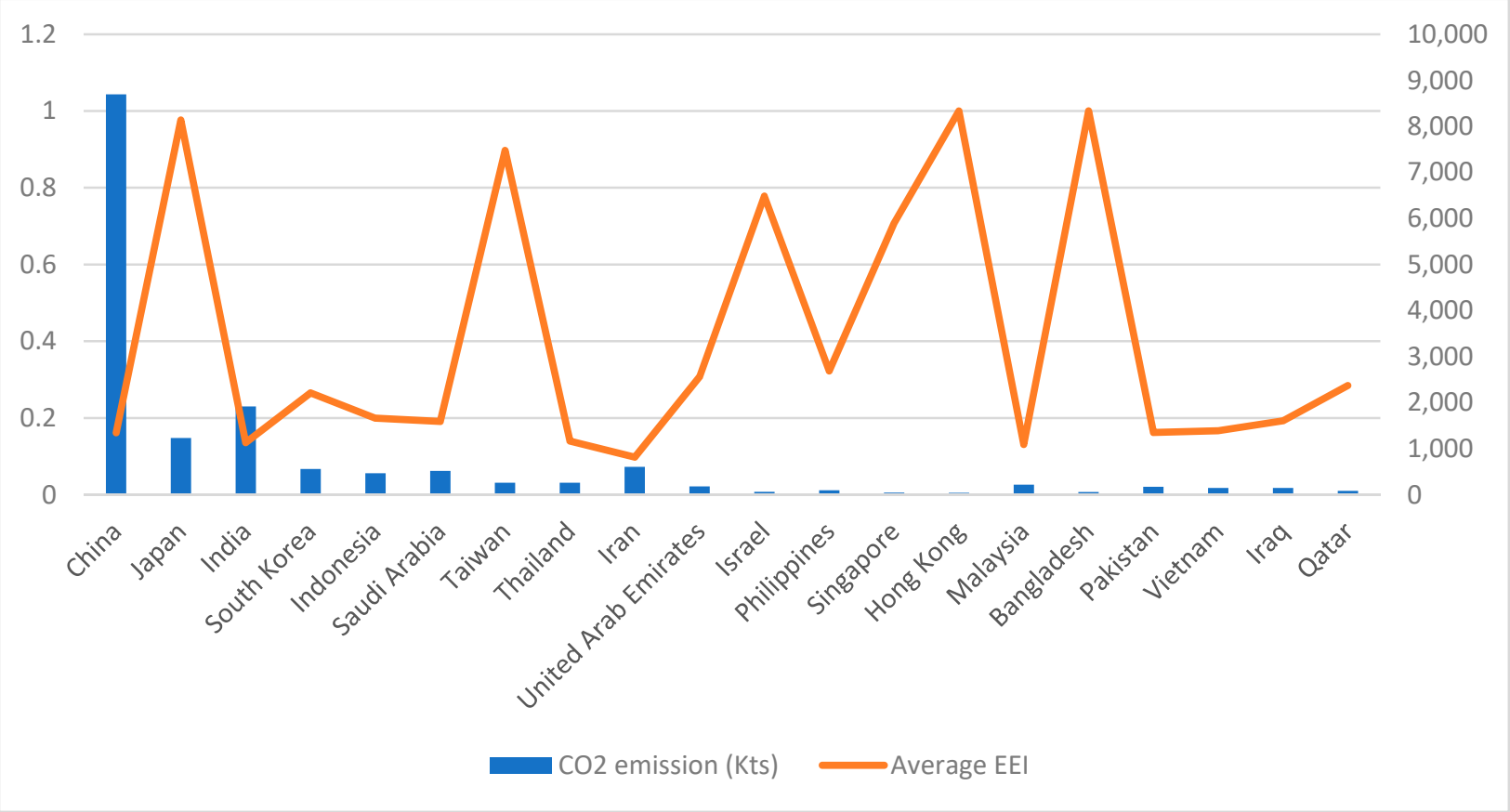

Figure 6. Comparison between the average EEI and the Average $\mathrm{CO}_{2}$ Emission. Source: authors' estimation.

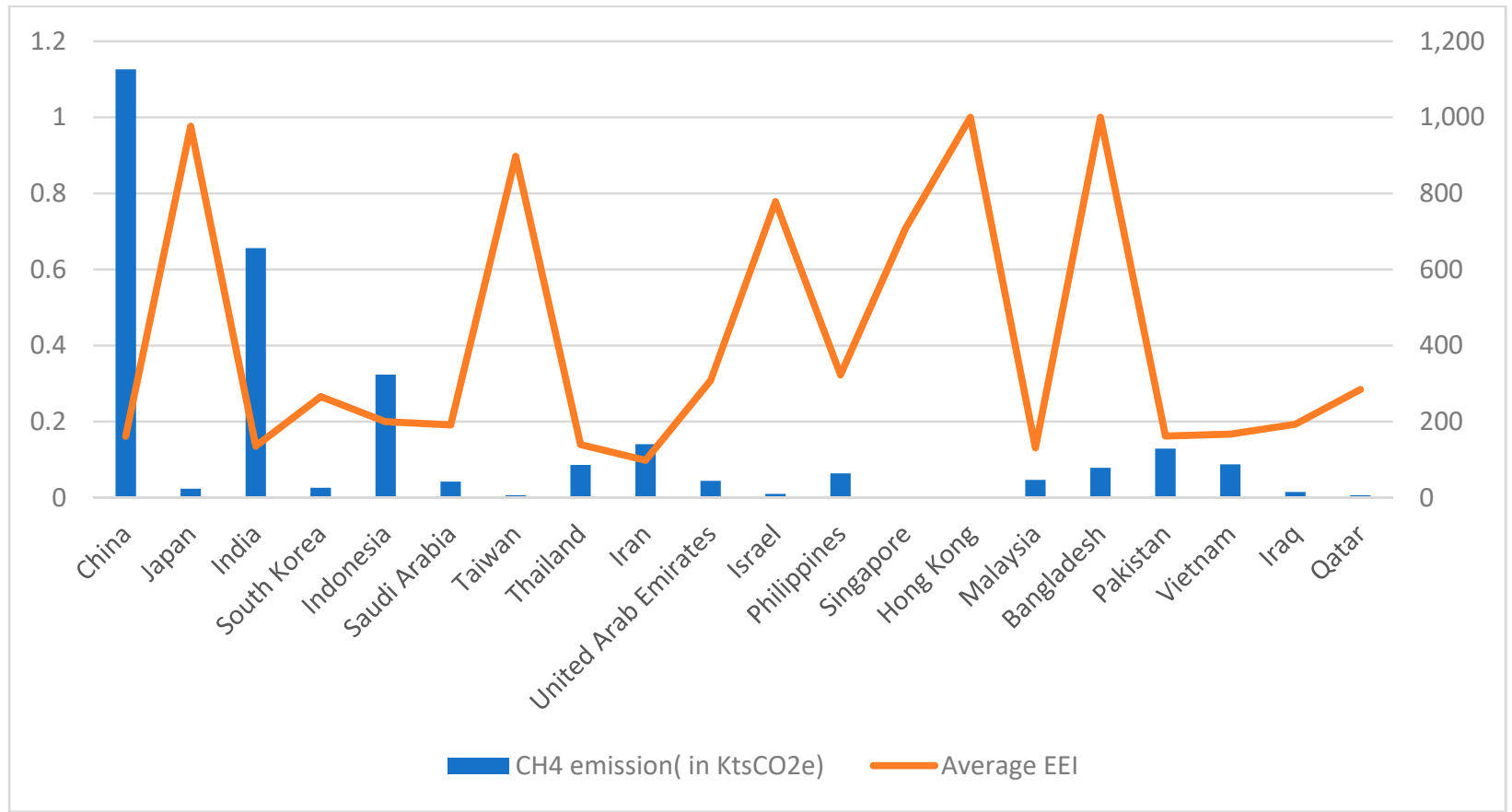

Figure 7. Comparison between the average EEI and the average $\mathrm{CH}_{4}$ emissions. Source: authors' estimation.

To confirm about the relationships above, the authors implemented correlation tests between the EEI and inputs/outputs in Table 7. The estimations in Table 7 confirm a positive association of a country's environmental efficiency with its energy consumption and a negative relation with undesirable amounts produced. It means that a country should consider controlling three key indicators, namely their energy consumption, amount of $\mathrm{CO}_{2}$ emissions, and amount of $\mathrm{CH}_{4}$ emissions, if they want to improve the environmental efficiency. 
Table 7. Correlation between the EEI and inputs/outputs with all data during 2005-2019. Source: authors' estimation.

\begin{tabular}{cccccccc}
\hline \multicolumn{10}{c}{ Correlations } \\
\hline
\end{tabular}

** Correlation is significant at the 0.01 level (2-tailed).

\subsection{Improving Methods of All Countries}

With projection in the analysis of variance, the environmental efficiency of countries can be improved by deleting the excess in inputs and bad outputs and augmenting the shortfalls in good outputs.

The projection of input factors of all countries in 2019 is presented in Table 8. For example, the DUM7 (Taiwan) has the value of environmental efficiency of 0.7366 , it can be improved by reducing $15.8 \%$ of the amount of energy consumption in 2019; as well as the volume of registered vehicles decrease $24.22 \%$. In addition, Table 8 shows the projections of output factors that Taiwan can consider in getting down $34.27 \%$ in the amount of $\mathrm{CO}_{2}$ emission; at the same time, there is no need for $\mathrm{CH}_{4}$ emission and GDP to change. The overall environmental efficiency of Taiwan can be upgraded, and its development is more sustainable with such changes above.

Table 8. Input/output factor projections. Source: authors' estimation.

\begin{tabular}{|c|c|c|c|c|c|c|c|c|c|c|c|}
\hline & & $\begin{array}{l}\text { (I) Energy } \\
\text { Consumption }\end{array}$ & & $\begin{array}{l}\text { (I) Volume } \\
\text { Vehicles }\end{array}$ & & (O) $\mathrm{CO}_{2}$ & & (O) $\mathrm{CH}_{4}$ & & (O) GDP & \\
\hline DMU & Score & Projection & $\begin{array}{c}\text { Change } \\
(\%)\end{array}$ & Projection & $\begin{array}{c}\text { Change } \\
(\%)\end{array}$ & Projection & $\begin{array}{c}\text { Change } \\
(\%)\end{array}$ & Projection & $\begin{array}{c}\text { Change } \\
(\%)\end{array}$ & Projection & $\begin{array}{c}\text { Change } \\
(\%)\end{array}$ \\
\hline DMU1 & 0.14 & 5101.00 & -0.80 & 8724.96 & -0.80 & 731.09 & -0.89 & 48.99 & -0.95 & 3550.34 & 0.00 \\
\hline DMU2 & 1.00 & 6126.68 & 0.00 & $75,715.00$ & 0.00 & 1302.52 & 0.00 & 26.42 & 0.00 & 4515.26 & 0.00 \\
\hline DMU3 & 0.15 & 1748.16 & -0.67 & 2990.12 & -0.90 & 250.55 & -0.82 & 16.79 & -0.97 & 1216.74 & 0.00 \\
\hline DMU4 & 0.32 & 1684.77 & -0.39 & 2881.70 & -0.82 & 241.47 & -0.51 & 16.18 & -0.38 & 1172.61 & 0.00 \\
\hline DMU5 & 0.17 & 620.99 & -0.60 & 1062.17 & -0.92 & 89.00 & -0.76 & 5.96 & -0.98 & 432.22 & 0.00 \\
\hline DMU6 & 0.20 & 597.64 & -0.70 & 1022.23 & -0.74 & 85.66 & -0.78 & 5.74 & -0.86 & 415.96 & 0.00 \\
\hline DMU7 & 0.74 & 1108.48 & -0.16 & 5088.33 & -0.24 & 179.64 & -0.34 & 9.06 & 0.00 & 783.80 & 0.00 \\
\hline DMU8 & 0.15 & 377.79 & -0.65 & 646.18 & -0.93 & 54.15 & -0.77 & 3.63 & -0.96 & 262.94 & 0.00 \\
\hline DMU9 & 0.11 & 502.70 & -0.78 & 859.83 & -0.90 & 72.05 & -0.86 & 4.83 & -0.96 & 349.88 & 0.00 \\
\hline DMU10 & 0.38 & 370.56 & -0.55 & 633.83 & -0.41 & 53.11 & -0.60 & 3.56 & -0.90 & 257.92 & 0.00 \\
\hline DMU11 & 0.45 & 257.12 & -0.04 & 439.79 & -0.80 & 36.85 & -0.41 & 2.47 & -0.69 & 178.96 & 0.00 \\
\hline DMU12 & 0.28 & 224.11 & -0.29 & 383.32 & -0.93 & 32.12 & -0.55 & 2.15 & -0.97 & 155.98 & 0.00 \\
\hline DMU13 & 0.48 & 259.97 & -0.60 & 444.66 & -0.37 & 37.26 & -0.22 & 2.50 & -0.04 & 180.94 & 0.00 \\
\hline DMU14 & 1.00 & 304.02 & 0.00 & 520.00 & 0.00 & 43.57 & 0.00 & 2.92 & 0.00 & 211.60 & 0.00 \\
\hline DMU15 & 0.13 & 278.08 & -0.69 & 475.64 & -0.94 & 39.86 & -0.78 & 2.67 & -0.94 & 193.55 & 0.00 \\
\hline DMU16 & 1.00 & 210.29 & 0.00 & 122.00 & 0.00 & 42.64 & 0.00 & 74.17 & 0.00 & 79.61 & 0.00 \\
\hline DMU17 & 0.15 & 218.94 & -0.70 & 374.49 & -0.87 & 31.38 & -0.80 & 2.10 & -0.98 & 152.39 & 0.00 \\
\hline DMU18 & 0.18 & 111.23 & -0.69 & 190.25 & -0.79 & 15.94 & -0.84 & 1.07 & -0.99 & 77.41 & 0.00 \\
\hline DMU19 & 0.17 & 127.64 & -0.61 & 218.32 & -0.91 & 18.29 & -0.70 & 1.23 & -0.90 & 88.84 & 0.00 \\
\hline DMU20 & 0.28 & 114.53 & -0.56 & 195.89 & -0.68 & 16.41 & -0.74 & 1.10 & -0.74 & 79.71 & 0.00 \\
\hline
\end{tabular}

However, it is much complicated to make such improvements in practice. There are many other factors that a government must take it into account. Although "green growth" or sustainable development are global trends, each country has a different orientation in its policies regarding many aspects, such as poverty, exclusion, unemployment, supporting the rule of law, economic position, and others.

\section{Conclusions}

By clearly defining the research topic, the authors were very successful in applying mathematical models to evaluate the environmental efficiency of the top 20 Asia economies during the period of 2005-2019. The study is a good reference for applying the undesirable output model in practical issues at the national level. Each country is determined optimally as a DMU through mathematical formulation with a precise selection of inputs and outputs. By separating bad outputs and good outputs, this is an outstanding DEA model 
in evaluating the effectiveness of DMUs. In this study, the bad indicators include $\mathrm{CO}_{2}$ and $\mathrm{CH}_{4}$ emissions that are two greenhouse gases directly impacting the global climate change. The advantage of our study is that the undesirable output model can evaluate the environmental efficiency indicators of all 20 countries and a fundamental foundation to propose an improvement plan related to the inputs/outputs of inefficient DMUs in practice. It is difficult to achieve this with other models such as stochastic frontier analysis, or Tobit. In addition, the results of the study have confirmed that governments encounter difficulties in making policy orientation. They have a trade-off between economic growth and environmental protection. For example, China and India are the two biggest economies in the Asia region, with their GDP of 14,343 and 2875 Bil.\$, respectively, in 2019; however, their environmental efficiency scores are very low, and it belongs to the "Improvable group" according to our ranking categories. Our data show that these two nations produced an enormous amount of bad outputs, such as $\mathrm{CO}_{2}$ and $\mathrm{CH}_{4}$. This can be explained by two reasons that we set as our input indicators, namely the number of registered vehicles and energy consumption from coal, oil, and gas.

It is clear to say that countries like China and India must consume a significant amount of energy in productions, transportation, services, and logistics to become the top economy in the region. Such activities lead to an increase in the amounts of harmful wastes and greenhouse gases. From our estimation, Hong Kong and Bangladesh are the two most efficiency over the period. In terms of GDP, meanwhile, Hong Kong and Bangladesh are ranked at the 14th and 16th, respectively, in 20 countries. It is no doubt to realize that the high-efficiency scores may be explained by the lower values of all indicators recorded in these two nations. However, there are many nations that have even been ranked lower position in the economy still have inefficiency of environmental concern, for instance, Pakistan, Vietnam, Iraq, and Qatar.

According to our model, there are two ways to have a high environmental efficiency. The first way is that countries need to reduce energy consumption and the volume of vehicles or the second way is to reduce the amount of $\mathrm{CO}_{2}$ and $\mathrm{CH}_{4}$ emission. It is very hard for a country to reduce energy consumption and the number of traffics because it may influence on the economy growth, especially in developing countries. The second one, therefore, can be a better solution with modern technological developments. Japan and Taiwan are two outstanding examples that the authors want to take it as benchmarks for other countries. The GDP of Japan and Taiwan is, respectively, $\$ 5082$ billion and $\$ 605$ billion, making them the top economies in the Asia region in 2019. The environmental efficiency of the two countries belong to "Good group" with the values of 0.98 and 0.9 in respective. These values are close to 1, which means "Excellent environmental efficiency". The authors figured out that Japan and Taiwan have been very good at controlling the bad outputs. Although energy consumption and the number of vehicles is recorded very high in these two countries, the amounts of $\mathrm{CO}_{2}$ produced in Japan and Taiwan are only 1:10 and 1:20, respectively, compared to the figures of China. Hence, the other countries can consider Japan and Taiwan as good references in the environmental efficiency if they want to develop sustainability.

In this study, the authors assumed that the weight of inputs and outputs are equal. Some research in the journal Nature indicates the amount of methane entering the atmosphere will increase several times when the temperature of the Earth rises by a degree [10]. The relative increase of methane emissions will overtake that of carbon emissions [37]. For further studies, hence, the authors suggest we should give a different weight between $\mathrm{CO}_{2}$ and $\mathrm{CH}_{4}$ in the research model. For example, Haro, Ouarma, and Nana (2019) [38] recommended giving a different weight of $\mathrm{CO}_{2}$ and $\mathrm{CH}_{4}$ because $\mathrm{CH}_{4}$ contributes 35 times more than that of $\mathrm{CO}_{2}$ to global warming. The efficiency value with such a method may be changed accurately. 
Author Contributions: Conceptualization, C.-N.W. and H.-P.N.; methodology, H.-P.N.; software, H.-P.N.; validation, H.-P.N., C.-N.W. and C.-W.C.; formal analysis, H.-P.N.; investigation, H.-P.N.; resources, H.-P.N.; data curation, H.-P.N.; writing-original draft preparation, H.-P.N.; writing-review and editing, H.-P.N., C.-N.W. and C.-W.C.; visualization, H.-P.N.; supervision, C.-N.W.; project administration, C.-N.W.; funding acquisition, C.-N.W. and C.-W.C. All authors have read and agreed to the published version of the manuscript.

Funding: This research was partly supported by the project number of 110G02 from National Kaohsiung University of Science and Technology, and project number of MOST 109-2622-E-992-026 from the Ministry of Sciences and Technology in Taiwan.

Institutional Review Board Statement: Not applicable.

Informed Consent Statement: Not applicable.

Acknowledgments: The authors appreciate the support from the National Kaohsiung University of Science and Technology and the Ministry of Sciences and Technology in Taiwan.

Conflicts of Interest: The authors declare no conflict of interest.

\section{Appendix A}

Table A1. List of common inputs/outputs for evaluating environmental efficiency by Data Envelopment Analysis (DEA) models.

\begin{tabular}{|c|c|c|c|c|}
\hline \multirow{2}{*}{ Authors } & \multicolumn{3}{|c|}{ Sample Characteristics } & \multirow{2}{*}{ Method } \\
\hline & Unit/Time Period & Inputs & Outputs & \\
\hline Hu and Kao (2007) [39] & $\begin{array}{l}17 \text { APEC } \\
\text { economies: } \\
\text { 1991-2000 }\end{array}$ & $\begin{array}{l}\text { (1) Energy consumption } \\
\text { (2) Labor } \\
\text { (3) Capital } \\
\text { (1) Labor }\end{array}$ & GDP & DEA CRS \\
\hline $\begin{array}{l}\text { Zhou and Ang } \\
\text { (2008) [40] }\end{array}$ & $\begin{array}{l}21 \text { OECD } \\
\text { countries: } \\
\text { 1997-2001 }\end{array}$ & $\begin{array}{l}\text { (2) Capital } \\
\text { (3) Coal consumption } \\
\text { (4) Oil consumption } \\
\text { (5) Gas consumption } \\
\text { (6) Other energy consumption }\end{array}$ & $\begin{array}{l}\text { (1) GDP } \\
\text { (2) } \mathrm{CO}_{2} \text { emission }\end{array}$ & $\begin{array}{l}\text { Environmental } \\
\text { CRS DEA }\end{array}$ \\
\hline $\begin{array}{l}\text { Gielen and } \\
\text { Taylor (2009) [41] }\end{array}$ & $\begin{array}{l}\text { Indian } \\
\text { industrial } \\
\text { sectors }\end{array}$ & Energy consumption & GDP & $\begin{array}{l}\text { IEA energy } \\
\text { efficiency index } \\
\text { based on } \\
\text { BAT/BPT }\end{array}$ \\
\hline Zhang et al.(2011) [42] & $\begin{array}{l}23 \text { developing } \\
\text { countries: } \\
\text { 1980-2005 }\end{array}$ & $\begin{array}{l}\text { (1) Labor } \\
\text { (2) Capital } \\
\text { (3) Energy consumption }\end{array}$ & GDP & VRS DEA \\
\hline Xie et al. (2014) [43] & $\begin{array}{l}\text { Electric power } \\
\text { Industries in } 26 \\
\text { OECD and } \\
\text { BRIC countries }\end{array}$ & $\begin{array}{l}\text { (1) Labor } \\
\text { (2) Installed capacity } \\
\text { (3) Fuel consumption } \\
\text { (4) Nuclear energy } \\
\text { consumption } \\
\text { (1) Labor }\end{array}$ & $\begin{array}{l}\text { (1) Electric power } \\
\text { (2) } \mathrm{CO}_{2}\end{array}$ & SBM-DEA \\
\hline $\begin{array}{l}\text { Moutinho et al. (2018) } \\
\text { [44] }\end{array}$ & $\begin{array}{l}16 \text { Latin America } \\
\text { countries }\end{array}$ & $\begin{array}{l}\text { (2) Capital } \\
\text { (3) Weight of fossil energy } \\
\text { (4) Share of renewable energy } \\
\text { in GDP }\end{array}$ & $\begin{array}{l}\text { (1) GDP } \\
\text { (2) Greenhouse gases }\end{array}$ & DEA Window \\
\hline Wang et al. (2021) [45] & $\begin{array}{l}42 \text { potential countries in } \\
\text { renewable energy }\end{array}$ & $\begin{array}{l}\text { (1) Population } \\
\text { (2) Total energy consumption } \\
\text { (3) Total renewable energy } \\
\text { capacity }\end{array}$ & $\begin{array}{l}\text { (1) GDP } \\
\text { (2) Total energy } \\
\text { production }\end{array}$ & $\begin{array}{l}\text { DEA Window and } \\
\text { Fuzzy TOPSIS model }\end{array}$ \\
\hline
\end{tabular}

Note: BRIC (Brazil, Russia, India, and China); OECD (Organization for Economic Cooperation and Development); SBM (slack-based measure.).

\section{References}

1. Song, M.; An, Q.; Zhang, W.; Wang, Z.; Wu, J. Environmental efficiency evaluation based on data envelopment analysis: A review. Renew. Sustain. Energy Rev. 2012, 16, 4465-4469. [CrossRef]

2. Zhu, W.; Xu, L.; Tang, L.; Xiang, X. Eco-efficiency of the Western Taiwan Straits Economic Zone: An evaluation based on a novel eco-efficiency model and empirical analysis of influencing factors. J. Clean. Prod. 2019, 234, 638-652. [CrossRef] 
3. Mathew, M.J.; Sautter, B.; Ariffin, E.H.; Menier, D.; Ramkumar, M.; Siddiqui, N.A.; Delanoe, H.; del Estal, N.; Traoré, K.; Gensac, E. Total vulnerability of the littoral zone to climate change-driven natural hazards in north Brittany, France. Sci. Total Environ. 2020, 706, 135963. [CrossRef] [PubMed]

4. Conrad, E.; Cassar, L.F. Decoupling Economic Growth and Environmental Degradation: Reviewing Progress to Date in the Small Island State of Malta. Sustainability 2014, 6, 6729-6750. [CrossRef]

5. Linda, C. The International Energy Outlook; Energy Information Administration: Washington, DC, USA, 2020.

6. EU. A Healthy and Sustainable Environment for Generations to Come; European Union: Brussels, Belgium, 2014.

7. Seiford, L.M.; Thrall, R.M. Recent developments in DEA: The mathematical programming approach to frontier analysis. J. Econ. 1990, 46, 7-38. [CrossRef]

8. Rogge, N.; De Jaeger, S. Evaluating the efficiency of municipalities in collecting and processing municipal solid waste: A shared input DEA-model. Waste Manag. 2012, 32, 1968-1978. [CrossRef]

9. Tsai, W.H.; Lee, H.L.; Yang, C.H.; Huang, C.C. Input-Output Analysis for Sustainability by Using DEA Method: A Comparison Study between European and Asian Countries. Sustainability 2016, 8, 1230. [CrossRef]

10. Hermoso-Orzáez, M.J.; García-Alguacil, M.; Terrados-Cepeda, J.; Brito, P. Measurement of environmental efficiency in the countries of the European Union with the enhanced data envelopment analysis method (DEA) during the period $2005-2012$. Environ. Sci. Pollut. Res. 2020, 27, 15691-15715. [CrossRef]

11. Wang, K.; Yu, S.; Zhang, W. China's regional energy and environmental efficiency: A DEA window analysis based dynamic evaluation. Math. Comput. Model. 2013, 58, 1117-1127. [CrossRef]

12. Li, K.; Lin, B. Metafroniter energy efficiency with CO 2 emissions and its convergence analysis for China. Energy Econ. 2015, 48, 230-241. [CrossRef]

13. Xu, T.; You, J.; Li, H.; Shao, L. Energy Efficiency Evaluation Based on Data Envelopment Analysis: A Literature Review. Energies 2020, 13, 3548. [CrossRef]

14. Farrell, M.J. The Measurement of Productive Efficiency. J. R. Stat. Soc. Ser. A (General) 1957, 120, 253-290. [CrossRef]

15. Wang, C.-N.; Nguyen, X.-T.; Wang, Y.-H. Automobile Industry Strategic Alliance Partner Selection: The Application of a Hybrid DEA and Grey Theory Model. Sustainability 2016, 8, 173. [CrossRef]

16. Pereira de Souza, M.V.; Diallo, M.; Castro Souza, R.; Baidya, T.K.N. The Cost Efficiency of the Brazilian Electricity Distribution Utilities: A Comparison of Bayesian SFA and DEA Models. Math. Probl. Eng. 2010, 30. [CrossRef]

17. Nguyen, P.; Nguyen, N.T. Using optimization algorithms of DEA and Grey system theory in strategic partner selection: An empirical study in Vietnam steel industry. Cogent Bus. Manag. 2020, 7, 1832810. [CrossRef]

18. Zhou, X.; Wang, Y.; Chai, J.; Wang, L.; Wang, S.; Lev, B. Sustainable supply chain evaluation: A dynamic double frontier network DEA model with interval type-2 fuzzy data. Inf. Sci. 2019, 504, 394-421. [CrossRef]

19. Cook, W.D.; Seiford, L.M. Data envelopment analysis (DEA)-Thirty years on. Eur. J. Oper. Res. 2009, 192, 1-17. [CrossRef]

20. Goto, M.; Otsuka, A.; Sueyoshi, T. DEA (data envelopment analysis) assessment of operational and environmental efficiencies on Japanese regional industries. Energy 2014, 66, 535-549. [CrossRef]

21. Tyteca, D. Linear programming models for the measurement of environmental performance of firms-concepts and empirical results. J. Prod. Anal. 1997, 8, 183-197. [CrossRef]

22. Golany, B.; Roll, Y. An application procedure for DEA. Omega 1989, 17, 237-250. [CrossRef]

23. Tone, K. A slack-based measure of efficiency in data envelopment analysis. Eur. J. Oper. Res. 2001, 130, 498-509. [CrossRef]

24. Feng, C.; Wang, M. Analysis of energy efficiency and energy savings potential in China's provincial industrial sectors. J. Clean. Prod. 2017, 164, 1531-1541. [CrossRef]

25. Cooper, W.W.; Seiford, L.M.; Tone, K. Introduction to Data Envelopment Analysis and Its Uses: With DEA-Solver Software and References; Springer Science and Business Media: Berlin, Germany, 2006.

26. Wu, X.; Tan, L.; Guo, J.; Wang, Y.; Liu, H.; Zhu, W. A study of allocative efficiency of PM2.5 emission rights based on a zero sum gains data envelopment model. J. Clean. Prod. 2016, 113, 1024-1031. [CrossRef]

27. Hu, J.-L.; Wang, S.-C. Total-factor energy efficiency of regions in China. Energy Policy 2006, 34, 3206-3217. [CrossRef]

28. Wang, C.-N.; Le, A.L.; Hou, C.-C. Applying Undesirable Output Model to Security Evaluation of Taiwan. Mathematics 2019, 7 , 1023. [CrossRef]

29. Halkos, G.; Petrou, K.N. Assessing 28 EU member states' environmental efficiency in national waste generation with DEA. J. Clean. Prod. 2019, 208, 509-521. [CrossRef]

30. Lee, P.; Park, Y.-J. Eco-Efficiency Evaluation Considering Environmental Stringency. Sustainability 2017, 9, 661. [CrossRef]

31. Yu, S.-H.; Gao, Y.; Shiue, Y.-C. A Comprehensive Evaluation of Sustainable Development Ability and Pathway for Major Cities in China. Sustainability 2017, 9, 1483. [CrossRef]

32. Wang, C.N.; Tibo, H.; Duong, D.H. Renewable Energy Utilization Analysis of Highly and Newly Industrialized Countries Using an Undesirable Output Model. Energies 2020, 13, 2629. [CrossRef]

33. Yvon-Durocher, G.; Allen, A.P.; Bastviken, D.; Conrad, R.; Gudasz, C.; St-Pierre, A.; Thanh-Duc, N.; Del Giorgio, P.A. Methane fluxes show consistent temperature dependence across microbial to ecosystem scales. Nat. Cell Biol. 2014, 507, 488-491. [CrossRef] [PubMed] 
34. Haro, K.; Ouarma, I.; Nana, B.; Bere, A.; Tubreoumya, G.C.; Kam, S.Z.; Laville, P.; Loubet, B.; Koulidiati, J. Assessment of CH4 and $\mathrm{CO}_{2}$ surface emissions from Polesgo's landfill (Ouagadougou, Burkina Faso) based on static chamber method. Adv. Clim. Chang. Res. 2019, 10, 181-191. [CrossRef]

35. OECD. Towards Green Growth in Southeast Asia; OECD Green Growth Studies; OECD Publishing: Paris, France, 2014.

36. Sherman, H.D.; Zhu, J. Service Productivity Management, Improving Service Performance Using Data Envelopment Analysis (DEA); Chapter 2: Data Envelopment Analysis Explained; Springer Science \& Business Media: Berlin, Germany, 2006.

37. Charnes, A.; Cooper, W.W.; Rhodes, E. Measuring the efficiency of decisión making units. Eur. J. Oper. Res. 1978, 2, 429-444. [CrossRef]

38. Ichimura, M.; Nam, S.; Bonjour, S.; Rankine, H.; Carisma, B.; Qiu, Y.; Khrueachotikul, R. Eco-Efficiency Indicators: Measuring Resource-Use Efficiency and the Impact of Economic Activities on the Environment; ESCAP: Bangkok, Thailand, 2009.

39. Hu, J.-L.; Kao, C.-H. Efficient energy-saving targets for APEC economies. Energy Policy 2007, 35, 373-382. [CrossRef]

40. Zhou, P.; Ang, B. Linear programming models for measuring economy-wide energy efficiency performance. Energy Policy 2008, 36, 2911-2916. [CrossRef]

41. Gielen, D.; Taylor, P. Indicators for industrial energy efficiency in India. Energy 2009, 34, 962-969. [CrossRef]

42. Zhang, X.-P.; Cheng, X.-M.; Yuan, J.-H.; Gao, X.-J. Total-factor energy efficiency in developing countries. Energy Policy 2011, 39, 644-650. [CrossRef]

43. Xie, B.C.; Shang, L.F.; Yang, S.B.; Yi, B.W. Dynamic environmental efficiency evaluation of electric power industries: Evidence from OECD (Organization for Economic Cooperation and Development) and BRIC (BrazilRussia, India and China) countries. Energy 2014, 74, 147-157. [CrossRef]

44. Moutinho, V.; Fuinhas, J.A.; Marques, A.C.; Santiago, R. Assessing eco-efficiency through the DEA analysis and decoupling index in the Latin America countries. J. Clean. Prod. 2018, 205, 512-524. [CrossRef]

45. Wang, C.N.; Dang, T.T.; Tibo, H.; Duong, D.H. Assessing Renewable Energy Production Capabilities Using DEA Window and Fuzzy TOPSIS Model. Symmetry 2021, 13, 334. [CrossRef] 